Citation: M. Fernández-Olmos, G. Malorgio (2020) The Speed of the Internationalisation Process and the Institutional Networks of Family SMEs in the DOC Rioja Wine Industry. Wine Economics and Policy 9(1): 43-50. doi: 10. $36253 /$ web-8371

Copyright: (c) 2020 M.F. Olmos, G. Malorgio. This is an open access, peer-reviewed article published by Firenze University Press (http://www. fupress.com/wep) and distributed under the terms of the Creative Commons Attribution License, which permits unrestricted use, distribution, and reproduction in any medium, provided the original author and source are credited.

Data Availability Statement: All relevant data are within the paper and its Supporting Information files.

Competing Interests: The Author(s) declare(s) no conflict of interest.
Original Research Article

\section{The Speed of the Internationalisation Process and the Institutional Networks of Family SMEs in the DOC Rioja Wine Industry}

\author{
Marta Fernández-Olmos ${ }^{1, *}$, Giulio Malorgio ${ }^{2}$ \\ ${ }^{1}$ University of Zaragoza, Spain. ${ }^{*}$ Corresponding author \\ ${ }^{2}$ University of Bologna, Italy \\ E-mail: maferno@unizar.es, giulio.malorgio@unibo.it
}

\begin{abstract}
Institutional networking is a key element in businesses' internationalisation processes and is an important strategy for promoting the long-term growth and survivability of family SMEs in the DOC Rioja wine industry. We hold that the proportion of family members in the TMT plays an important role in strategic decision-making and helps to explain the speed of their internationalisation process. This paper contributes to the scant research on the influence of family involvement in the TMT by analysing the moderating effects of two diversities on the relationship between institutional networking and the speed of internationalisation: the family TMT ratio and generational involvement. Using a broad sample of 77 family wineries in DOC Rioja, the results obtained indicate that institutional networking plays a significant role in explaining the speed of internationalisation in family firms and that this relationship is weaker when a larger proportion of family members serve as top managers. The empirical results also have interesting implications for the managers of family firms as it may help them to identify the effective composition of TMTs to be considered when deciding on the process of internationalisation.
\end{abstract}

Keywords: institutional networking, speed of internationalisation, DOC Rioja wine.

\section{INTRODUCTION}

Institutional networking of the firm, the firm's network relationships with institutional actors (e.g., research institutions, advisory and support offices, independent export assistant organisations, export promotion councils, etc.), is a key element in businesses' internationalisation processes (Séror, 1998; Bateman, 2000).

In the specific case of Rioja Certified Designation of Origin (DOC Rioja) wineries, institutional networking has been identified as a key success factor in their bid to expand their business to international markets. To overcome the barriers that family SME wineries encounter when accessing international markets, many have been able to count on and benefit from collaborations with institutions. One example is the Family Winery Association of Rioja PROVIR, which represents Spanish family wineries in the European 
Confederation of Independent Winegrowers, with 8,000 independent European winegrowers.

Previous and recent literature has acknowledged that the presence of family members chairing the board and their experience are important determinants in the internationalisation of family SMEs (Pukall \& Calabro, 2014). However, most research on family business internationalisation has largely ignored the possible effect of individual managerial levels of knowledge and experience on the speed of internationalisation for SMEs.

According to Zahra (2003), when family members are in top management team (TMT) positions, which is very common in family SMEs (Speckbacher \& Wentges, 2012), they may approach internationalisation with caution. This involvement of family members in management prompts unique strategic behaviours, influences the decisions that manage resources, and may influence internationalisation strategies and practices (Abdellatif et al., 2010). The influence of family involvement in SMEs offers a unique environment in which to analyse whether and to what extent a firm's family character affects the speed of the internationalisation process.

To address this gap, we examine the moderating role of family involvement in the institutional networkinginternationalisation relationship. According to previous literature (Arzubiaga, Maseda, \& Iturralde, 2019), the identity of the TMT (the diversity between family and non-family managers) and the involvement of multiple generations (the diversity among two or more generations of family members that work together in the TMT) are the two main forms of TMT diversity created by the family's involvement. We consider that there could be a relation between TMT diversity and the firm's speed of internationalisation and that a more fine-grained examination of family influence, using these two family involvement measures, is needed to gain a clear and precise understanding of how they affect the process.

To the best of our knowledge, this is the first study concerned with how institutional networking's effect on the speed of the internationalisation process may be moderated due to family-related factors. The context of the DOC Rioja wine industry is particularly noteworthy because DOC Rioja wine producers, as members of the European wine sector, are making efforts to increase export volumes due to declining consumption in the domestic market (Köhr, Malorgio, \& Aragrande, 2017; Köhr, Camanzi and Malorgio, 2018). Our study also aims to contribute with new knowledge regarding how strategic behaviour and the speed of internationalisation process may differ, not only between family and nonfamily firms but also between family firms with different attributes, showing that family firms are heterogene- ous (Sharma, Melin, \& Nordqvist, 2014). One important differentiating attribute is the varying level of family involvement in the TMTs, which can be a more important driver of variation, in terms of success, when turning institutional networking into internationalisation among family SMEs than was suggested by previous literature. Moreover, the study contributes to understanding the heterogeneity of the family firm internationalisation processes, highlighting the importance of effects of the family business governance dimensions (Baronchelli et al., 2016).

\section{THEORETICAL BACKGROUND AND DEVELOPMENT OF THE HYPOTHESES}

Although family firms have mainly tended to focus on domestic markets, they increasingly focus on foreign markets as a survival strategy due to global competition and slow growth domestically (Pukall \& Calabrò, 2014).

It is well known that family firms suffer from inherent constraints to international growth (Fernández \& Nieto, 2005; Abdellatif et al., 2010). To overcome the limitation of internal resources for internationalisation, family firms can develop network associations with institutional partners such as governments, agencies for international development, research institutions, and so on. These institutional networks can help family SMEs gain knowledge of international markets and the current rules and regulations (Kontinen and Ojala, 2011a,b). In particular, they provide a variety of support services aimed at reducing risks and providing access to required resources and capabilities when these firms enter international markets (Séror, 1998). A key objective of this type of network association is to help family firms to build international contacts and allow them to assess their abilities to identify and exploit international opportunities (Szyliowicz \& Galvin, 2010; Bateman, 2000). In the specific case of the Rioja wine industry, an example of recent institutional collaboration by the Board of the Rioja Designation of Origin was its participation in the background work for establishing and implementing an internationalisation strategy for La Rioja (Annual Report of DOC Rioja, 2018)

Using these institutional networks not only creates opportunities for family firms to internationalise but also provides them with links to accelerate their internationalisation process.

Recent literature recognises the diversity in family firms in several areas, such as family involvement in ownership and management (Beck, Janssens, Debruyne, \& Lommelen, 2011; Nordqvist, Sharma, \& Chirico, 2014). According to Pukall \& Calabrò (2014), family firm het- 
erogeneity could help to understand behaviours in their internationalisation. This study focuses on the level of family involvement in the firms' TMTs; which seems to be an important determinant of the speed of the internationalisation process and whose relevance has been underestimated (Alayo et al., 2019).

Following Alayo et al. (2019), we focus on two sources of TMT diversity: generational involvement, i.e., whether there are multiple family generations simultaneously involved in the firms' TMTs (Sciascia, Mazzola, \& Chirico, 2013), and the proportion of family members inside the TMTs, which may be important in explaining variations in performance. Generational involvement can be conceived as a proxy of knowledge diversity in multigenerational family TMTs (Sciascia et al., 2013). Within the family business literature, there exist some theoretical discussions arguing in favour and others against the degree of presence of family members in the TMT (Minichilli, Corbetta, \& MacMillan, 2010).

Internationally experienced management teams have a greater ability to process information and face intense competition, and thus have a greater propensity to develop higher levels of internationalisation. However, family firms do not have the capacity to succeed and endure in the global competitive market due to a lack of the knowledge and management skills needed to run them (Banalieva \& Eddleston, 2011; Gómez-Mejía, Makri, \& Kintana, 2010). This can be important when developing international markets, because non-family managers tend to expand from domestic to international markets through existing relationships (Liang, Wang, \& Cui, 2014). Specifically, non-family managers in TMTs have a greater diversity of specialised skills and knowledge than family members that often have the same background and lack international experience. Taking into account that more diverse management teams tend to be more creative and innovative, including non-family managers may strengthen the positive relationship between social capital and a family firm's speed of internationalisation. Thus, TMSs with family managers, whose composition reflects a weak diversity of backgrounds, knowledge, experience and abilities, are expected to reduce the positive relationship between institutional networking and a firm's speed of internationalisation. Building on this line of reasoning, we propose the following:

H1. A greater proportion of family members in the TMT will negatively influence the effect of institutional networking on family SMEs' speed of internationalisation.

According to Chirico, Sirmon, Sciascia, \& Mazzola (2011), experiences and knowledge tend to differ more across generations than within a single generation (Chirico et al., 2011), because family members from different generations achieve different levels of formal education and experience outside the business before joining the firm (Talke et al., 2011) and have different social relationships (Arregle, Hitt, Sirmon, \& Very, 2007). While later generations are characterised by more formal education, older generations have more tacit knowledge and experience in the business. Thus, the involvement of several generations in TMTs provides a synergistic combination of capabilities that are useful for intensifying social capital's effect on family firms' speed of internationalisation.

Some studies do argue, however, that maintaining family management of the business across generations can increase complexity (Sciascia et al., 2013), because it is easier to share interests and understand the intentions and actions of actors within a generation rather than across several generations. This may lead to control and coordination problems as each family member is trying to protect his or her own personal interests in the firm (Ling \& Kellermanns, 2010; Sciascia et al., 2013). Therefore, managing the transgenerational orientation of TMTs in family firms makes conflict particularly pervasive, which makes it difficult to achieve consensus around strategic decisions (Michie, Dooley, \& Fryxell, 2006). Therefore, some of the elements that intergenerational involvement brings to the management of family firms are positive and some are negative. When there are several generations in the TMT, family firms benefit from it in terms of expertise diversity, but relationships can be more complex and communication more difficult (Sciascia et al., 2013).

From the above, we might conclude that the impact of institutional networking follows a different pattern for family firms with several generations than for those with a single generation in management. Therefore, we posit the following:

H2. Multigenerational family in the TMT will positively moderate the effect of institutional networking on family SMEs' speed of internationalisation.

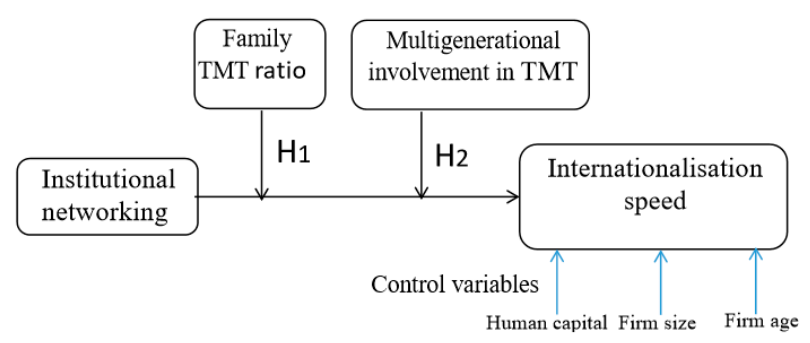

Figure 1. The proposed model. 


\section{METHODOLOGY}

The main data sources used to obtain the list of wineries in the target population were the directories drawn up by the Regulatory Council of the Rioja Designation of Origin (the number of wineries in this directory numbered 580). The data for this study were collected using a structural survey. The data collection period ended in September 2017. The population from which the sample is drawn consists of wineries that fulfil the following requirements: (1) they belong to the Rioja Designation of Origin, (2) they manage the full winemaking process from grape to bottle, and (3) they are obliged to present accounting information to the authorities. In total, 123 valid questionnaires were obtained. For the purpose of this research, we focused on exporting firms and family firms. Although a consensus around what is exactly meant by family businesses is still missing in the literature, academics recognise that family involvement in ownership and management play a decisive role. Therefore, firms in this study are considered family-firms if they meet three requirements: (1) majority ownership is controlled by a single family; (2) the family actively participates in firm management; and (3) they were self-classified as family businesses by answering the questions related to generational transfer. Seventyseven firms that fulfilled all the conditions were identified in the sample. All of them were considered as SMEs because they have fewer than 250 employees.

We examined previous literature to measure all variables. The dependent variable, internationalisation speed, is measured by analysing international market expansion strategies in terms of the timing and scope of the foreign markets entered (Lee and Yang, 1990; Ruzo et al., 2011). In keeping with the approach used by Lee and Yang (1990), we first divided the sample into firms with less or more experience in international activities with five years selling abroad as the cut-off point. Those firms placed in the group with less international experience and operating in up to five countries were categorised as the low speed group. Firms with more international experience, and operating in up to 12 countries, were also placed in the low speed group. The rest of the firms were classified as the high-speed group. In total, 48 wineries were classified in the low speed group and 29 wineries in the high-speed group.

Institutional networking includes the network of relationships with formal institutions. In the context of this study, an important institution is PROVIR (Asociación Bodegas Familiares de Rioja). Belonging to this association allows family wineries to be affiliated with a global brand "Independent Family Wineries". This allows them to become familiar with the global business environment (e.g., by launching marketing campaigns abroad), including knowledge about their competitors and an awareness of international standards, requirements and quality. Other important formal institutions in this context are ARAEX (Asociación de Exportadores de Rioja Alavesa), ARBOR (Agrupación de Artesanos Bodegueros de Rioja), ABC (Asociación de Bodegas por la Calidad), FECOAR (Federación de Cooperativas Agrarias de La Rioja), ABRA (Asociación de Bodegas de Rioja Alavesa), AEVZR (Asociación de Empresas Vinícolas de la Zona Rioja), Instituto de Ciencias de la Vid y del Vino, Estación Enológica de Haro, Grupo de Empresas Vinícolas de Rioja, Proyecto Europeo Wine Tech, El Grupo Rioja, University of La Rioja, University of Basque Country-Campus Álava, University of Navarra, etc. The questionnaire provides a list of institutions and we count the institutions chosen.

The study analyses two moderating variables. To compute the family TMT ratio, respondents were asked to indicate the number of family members holding managerial positions and the total number of TMT members. This percentage is measured as a continuous variable. To measure multigenerational involvement, respondents were asked to indicate which family generation, at present, is in charge of ownership and management. We created a dummy variable, which takes value 1 when there are two or more family generations involved and 0 otherwise.

In addition to the above measures, two control variables were included: human capital and size. We used the proportion of employees with a university degree as a proxy for human capital (Fernández-Olmos, 2011). Company size was operationalised using the natural logarithm of the number of employees (e.g., Hessels and Terjesen, 2010).

We also control for family firm age in the analysis. Following prior empirical studies (e.g., Majocchi et al., 2005), we measure experience as the number of years that a family firm has in the winemaking activity.

\section{EMPIRICAL TESTING}

Since the dependent variable (the speed of internationalisation) is a binary variable, a binomial logit model is applied as the means of estimation (Greene, 2003). In table 1 we present marginal effects from this model. The choice of the binomial logit model for the estimation of our model is appropriate, since the model presents satisfactory indicators of overall significance.

The effect of institutional networks on the speed of internationalisation is positive and statistically signifi- 
Table 1. Binomial logit model (average marginal effects).

\begin{tabular}{lcc}
\hline Independent variables & $\begin{array}{c}\text { Marginal } \\
\text { effects }\end{array}$ & P> I z I \\
& $\begin{array}{lc}\text { (dy/dx) } \\
\text { Institutional networking }\end{array}$ & \\
\hline Institutional networking*Family TMT ratio & -0.536 & 0.054 \\
Institutional networking* Multigenerational & 0.118 & 0.048 \\
involvement & 0.423 \\
Human capital & 0.006 & 0.008 \\
Size & 0.120 & 0.073 \\
Age & -0.164 & 0.093 \\
\hline $\mathrm{N}$ & 77 & \\
McFadden's $\mathrm{R}^{2}$ & 0.202 & \\
Likelihood ratio Test & 20.57 & \\
Chi-square statistic & 0.002 & \\
\hline
\end{tabular}

cant at the 0.10 level; the results suggest that family wineries in DOC Rioja can greatly improve their internationalisation speed by effectively generating network ties.

The moderating effect produced by the family TMT ratio is negative and significant and hypothesis 1 is thus not rejected. It is suggested that the effect of institutional networks on the speed of internationalisation is lower in family wineries with a higher proportion of family members in the managerial team. However, the moderating effect produced by multigenerational involvement is positive but not significant, thereby rejecting our second hypothesis.

Other control variables remain statistically significant. In particular, variable human capital is positive and significant, suggesting that firms that hire talented employees are more likely to have a greater speed of internationalisation. The coefficient indicating size was also marginally significant, indicating that size is a significant feature for a rapid process of internationalisation. Finally, there is evidence that age only influences very slightly the speed of internationalisation.

\section{DISCUSSION}

The purpose of this paper was to analyse the extent to which family TMT involvement influences the relationship between institutional networking and the speed of internationalisation of family SMEs. It advances our understanding of how family involvement in firms (in particular, the family TMT ratio and multigenerational family) affects the role of TMT. Interestingly, the literature review of the upper echelons theory revealed the idea that firms will be a reflection of the composition of their top management team, in particular their heterogeneity (Hambrick, 2007).

The relative heterogeneity or diversity of the characteristics (e.g., training, abilities, aptitudes, etc.) of team members may influence the speed of internationalisation. Our empirical analysis improves our understanding of family firms' institutional networking and the speed of internationalisation in three ways. First, it extends the literature on upper echelons theory, showing empirical evidence of the impact of TMT heterogeneity on family SMEs' speed of internationalisation. Our results support our first hypothesis that the family TMT ratio has a negative effect on the relationship between institutional networking and the speed of internationalisation, as the relationship is weaker when a larger proportion of family members serve as top managers. This is due to the low availability of diverse perspectives and knowledge in decision-making processes when family involvement is excessive. In this respect, Dyer (2006) suggests that family firms are constrained by their limited pool of human capital and their TMTs often lack qualified employees. For this reason, hiring non-family members for the TMT may transform the family firm into a more professional business (Dyer, 1989), bringing specific skills, formal training and idiosyncratic knowledge, and thus, help them overcome the inherent limitations of family management (Segaro et al., 2014). Thus, our results suggest that family firms that wish to quickly penetrate international markets must hire and maintain experienced and skilled non-family members for their TMTs to improve the institutional networking effect on the speed of internationalisation.

The present study contends that a multigenerational family presence in the TMT positively influences the effect of institutional networking on family firms' speed of internationalisation. The underlying idea is that generational involvement is conceived as a proxy of knowledge diversity in multigenerational family TMTs (Sciascia, 2013). However, our results do not support this second hypothesis. Rather, they show that involving a larger number of generations generates a positive but not significant moderating effect. This lack of evidence of the effect of generational involvement allows us to propose the following interpretation. Multigenerational family businesses involve hierarchical and asymmetric relationships among members of different generations (WadeBenzoni, 2002), where communication problems, different priorities and anachronistic mentalities are factors which create a negative climate. This would reduce the benefits of having a more heterogeneous TMT with the presence of multiple generations. 


\section{CONCLUSIONS}

This paper aims to make several contributions to the under-researched and poorly understood phenomenon of the internationalisation process in family firms (Arregle et al., 2019).

First, our findings contribute to recent research on family firm heterogeneity, which has been insufficiently examined when studying the internationalisation of family firms (Arregle et al., 2019). Ignoring this could lead to an inaccurate understanding of the process (Melin and Nordqvist, 2007).

Family firms are heterogeneous as they differ in terms of the extent and mode of family involvement in the TMT. Dimensions of family firm governance are discussed, and our study focuses on how governance influences the speed of internationalisation, moderating the effect of institutional networking.

Second, our study contributes to the scant research on the influence of family involvement in the TMT and the internationalisation process in family firms (Arregle et al., 2019) by showing how family TMT heterogeneity, as a distinctive characteristic of family firms, does influence the relationship between institutional networking and the speed of internationalisation. This knowledge contributes to the upper echelons theory on family firms by increasing our understanding of the impact of two diversities that are found specifically in family firm TMTs: the family TMT ratio (i.e., the proportion of family members in the TMT) and generational involvement (i.e., presence of multiple generations in the TMT). We choose these two family firm-specific diversities, which are found only in family firms, because they have been previously analysed in research on entrepreneurial orientation (Alayo et al., 2019) or innovation (Kraiczy et al., 2015; Arzubiaga et al., 2019) in family firms, but not in the relationship between institutional networking and speed of internationalisation.

Based on the upper echelons theory, we show that the proportion of family members in the TMT plays an important role in strategic decision-making and moderates the existing positive relationship between institutional networking and the speed of internationalisation. Our results also suggest that generational involvement in the TMT is a double-edged sword with advantages and disadvantages. On the one hand, with the presence of diverse younger generations may benefit from the experience and different knowledge backgrounds of older generations. On the other hand, older generations tend to be more risk-averse than previous generations when it comes to expanding to foreign markets. This can explain why the expected positive effect was not significant. There- fore, future research efforts should validate our findings with regard to these two family firm-specific diversities by using larger and more heterogeneous samples.

Third, we contribute to the literature combining international business and family firms by providing a potential explanation for why family firms are able to internationalise quickly. Little research exists on family firms' institutional networking and the internationalisation of family firms, and in particular, on the dimension of the speed of internationalisation. To the best of our knowledge, this is the first study to analyse how the effect of institutional networking on the speed of internationalisation may vary because of family influence.

Specific family firm characteristics (i.e., family involvement in TMT) can facilitate a set of strategic decisions related to internationalisation. Thus, this paper argues that the relationship between a family firm and the speed of internationalisation is a highly complex issue that needs further research.

Fourth, our study aims to serve as a turning point in the investigation of the family wine sector. Family firms are the most common type of business in the wine industry, but their gradual or accelerated process of internationalisation has not been investigated in depth although it has become significant. Our results are based on a comprehensive new data set on institutional networking, family firm characteristics, and internationalisation, for a broad sample of 77 family wineries in DOC Rioja, a context where almost $90 \%$ of wineries are considered family firms according to AREF (Asociación Riojana de Empresa Familiar, https://www.aref.es/). It would be interesting for future studies to analyse other dimensions of internationalisation of family firms and their variations due to the influence of family-related factors in other settings.

The results obtained also have interesting implications for the managers of family firms, because it may help them to identify the effective composition of TMTs to be considered when deciding on the process of internationalisation. Our findings suggest that the presence of family managers in TMT positions can be an obstacle as regards increasing the speed of the internationalisation process. To overcome these barriers, it non-family members should participate in TMTs because they accumulate, develop and transfer external market knowledge and experiences that can enhance the effect of institutional networking during the process of entering an international market. Non-family managers can also mitigate problems among family members by infusing a broader, organisationally rational perspective into their practices (Alayo et al. 2019).

With regard to the presence of multiple generations in TMT positions, the effect is ambiguous. Each gen- 
eration of a family business tends to have different priorities related to management and future strategies. This can affect their internationalisation business interests if there is a lack of coordination and mutual understanding amongst family members. Consequently, and in line with the work of Alayo et al. (2019), family firms should try to align the interests of business for non-family and family members of different generations involved in the TMT to lead to a valuable collaboration regarding knowledge transfer and decision-making.

However, our results must be viewed in the light of the study's limitations. Empirical data were obtained only from DOC Rioja wine family businesses. Therefore, the findings may not be generalizable to other environments. However, we consider that this sample is valuable in explaining why some family firms exhibit divergent behaviour with regard to the speed of internationalisation for two reasons. First, the use of this homogenous, industry-specific sample permits us to concentrate on the more firm-specific variables, and second, the research on family businesses in the wine sector is practically non-existent (Soler et al., 2017). Moreover, we conduct a cross-sectional study due to a lack of longitudinal information, which presents the disadvantage of not capturing the dynamic nature of the hypotheses tested in this study. Therefore, future research should take a dynamic approach into account to gain more insight into the relationship between institutional networking and the speed of internationalisation.

In spite of these limitations, this paper sheds light on the process of decision-making with regard to the internationalisation process in family firms. It could help guide policy makers in designing stimulation programmes to motivate family firms, particularly wineries, to organize their TMTs depending on their internationalisation needs.

\section{AKNOWLEDGEMENT}

This research was supported by project grant ECO2016-77-P (AEI/FEDER, UE) , the COMPETE (S52_17R) research group (Government of Aragón -Spain- and FEDER 2014-2020 "Construyendo Europa desde Aragón") and by project VINCI SOE3/P2/F0917.

\section{REFERENCES}

Abdellatif, M., Amann, B., Jaussaud, J. 2010. Family versus nonfamily Business: A comparison of International strategies. J. Family Bus. Strat. 1(2), 108-116.
Alayo, M., Maseda, A., Iturralde, T., Arzubiaga, U. 2019. Internationalisation and entrepreneurial orientation of family SMEs: The influence of the family character. Int. Bus. Rev. 28, 48-59

Annual Report of DOC Rioja https://www.riojawine. com/wp-content/uploads/1/2019/06/MEMORIA_ ENG_2018_web.pdf

Arregle, J., Hitt, M.A., Sirmon, D.G., Very, P. 2007. The development of organizational social capital: attributes of family firms. J. Manag. Stud. 44 (1), 73-95

Arregle, J. L., Hitt, M. A., Mari, I. 2019. A missing link in family firms' Internationalisation Research: Family structures. J. Int. Bus. Stud. 1-17.

Arzubiaga, U., Maseda, A., Iturralde, T. 2019. Exploratory and exploitative innovation in family Businesses: the moderating role of the family firm image and family involvement in top Management. Rev. Manag. Science 13(1), 1-31

Banalieva, E. R., Eddleston, K. A. 2011. Home-region focus and performance of family firms: The role of family vs non-family leaders. J. Int. Bus. Stud. 42(8), 1060-1072.

Baronchelli G, Bettinelli C, Del Bosco B, Loane, S. 2016. The impact of family involvement on the investments of Italian small-medium enterprises in psychically distant countries. Int. Bus. Rev. 25, 960-970

Bateman, M. 2000. Neo-liberalism, SME development and the role of Bus. Support Centres in the transition economies of Central and Eastern Europe. Small Bus. Econ. 14(4), 275-298

Beck, L., Janssens, W., Debruyne, M., Lommelen, T. 2011. A study of the relationships between generation, market orientation, and innovation in family firms. Family Bus. Rev. 24(3), 252-272.

Chirico, F., Sirmon, D. G., Sciascia, S., Mazzola, P. 2011. Resource orchestration in family firms: Investigating how entrepreneurial orientation, generational involvement, and participative strategy affect performance. Strat. Entrep. J. 5(4), 307-326.

Fernández, Z., Nieto, M. J. 2005. Internationalisation strategy of small and medium-sized family Businesses: Some influential factors. Family Bus. Rev. 18(1), 77-89.

Fernández-Olmos, M. 2011. The determinants of Internationalisation: Evidence from the wine industry. Appl. Econ. Perspect. Policy 33(3), 384-401.

Gomez-Mejia, L. R., Makri, M., Kintana, M. L. 2010. Diversification decisions in family-controlled firms. J. Manag. Stud. 47(2), 223-252.

Greene, W. H. 2003. Econometric analysis. Pearson Education India.

Hessels, J., Terjesen, S. 2010. Resource dependency and institutional theory perspectives on direct and indirect export choices. Small Bus. Econ. 34(2), 203-220. 
Köhr, C. K., Malorgio, G., Aragrande, M. 2017. Exploring determinants of internationalisation: the case of late starters. Int. J. Wine Bus. Res. 29 (2), 159-177.

Köhr, C. K., Camanzi, L., Malorgio, G. 2018. Exploring structural and strategic correlates of difficulties in the Int.isation process of Italian wine SMEs. Wine Econ. Policy 7(1), 13-23

Kontinen, T., Ojala, A. 2011a. Network ties in the international opportunity recognition of family SMEs. Int. Bus. Rev. 20(4), 440-453.

Kontinen, T., Ojala, A. 2011b. International opportunity recognition among small and medium-sized family firms. J. Small Bus. Manag. 49(3), 490-514.

Kraiczy, N. D., Hack, A., Kellermanns, F. W. 2015. What makes a family firm innovative? CEO risk-taking propensity and the organizational context of family firms. J. Prod. Innov. Manag. 32(3), 334-348.

Lee, C.S., Yang, Y.S. 1990. Impact of export market expansion strategy on export performance. Int. Mark. Rev. 7 (4), pp. 41-51.

Ling, Y., Kellermanns, F.W. 2010. The effects of family firm specific sources of TMT diversity: The moderating role of information exchange frequency. J. Manag. Stud. 47 (2), 322-344.

Liang, X., Wang, L., Cui, Z. 2014. Chinese private firms and Internationalisation: Effects of family involvement in Management and family ownership. Family Bus. Rev. 27(2), 126-141.

Majocchi, A., Bacchiocchi, E., Mayrhofer, U. 2005. Firm size, business experience and export intensity in SMEs: A longitudinal approach to complex relationships. Int. Bus. Rev. 14(6), 719-738.

Melin, L., Nordqvist, M. 2007. The reflexive dynamics of institutionalization: The case of the family business. Strat. Organ. 5(3), 321-333.

Michie, S. G., Dooley, R. S., Fryxell, G. E. 2006. Unified diversity in top-level teams: Enhancing collaboration and quality in strategic decision-making. Int. J. Organ. Anal. 14(2), 130-149.

Minichilli, A., Corbetta, G., MacMillan, I. C. 2010. Top management teams in family-controlled companies: 'familiness', 'faultlines', and their impact on financial performance. J. Manag. Stud. 47(2), 205-222.

Nordqvist, M., Sharma, P., Chirico, F. 2014. Family firm heterogeneity and governance: A configuration approach. J. Small Bus. Manag. 52(2), 192-209.

Pukall, T. J., Calabrò, A. 2014. The Internationalisation of family firms: A critical review and integrative model. Family Bus. Rev. 27(2), 103-125

Ruzo, E., Losada, F., Navarro, A., Díez, J.A. 2011. Resources and International marketing strategy in export firms: Implications for export performance. Manag. Res. Rev. 34 (5), 496-518.

Sciascia, S., Mazzola, P., Chirico, F. 2013. Generational involvement in the top Management team of family firms: Exploring nonlinear effects on entrepreneurial orientation. Entrep. Theory Pract. 37(1), 69-85.

Séror, A. C. 1998. A model of institutional network dynamics and a comparative case analysis of information technology transfer. J. Tech. Transfer 23(3), 39-50.

Sharma, P., Melin, L., Nordqvist, M. 2014. Future of Family Business Studies, 2007, 1-22, in L. Merlin, M. Nordqvist, M. and P. Sharma (Eds.). The Sage Handbook of Family Business. London, UK: Sage Publications LTD

Soler, I. P., Gemar, G., Guerrero-Murillo, R. 2017. Family and non-family business behaviour in the wine sector: A comparative study. Eur. J. Family Bus. 7(1-2), 65-73.

Speckbacher, G., Wentges, P. 2012. The impact of family control on the use of performance measures in strategic target setting and incentive compensation: A Res. note. Manag. Accounting Res. 23 (1), 34-46.

Szyliowicz, D., Galvin, T. 2010. Applying broader strokes: Extending institutional perspectives and agendas for international entrepreneurship research. Int. Bus. Rev. 19(4), 317-332.

Talke, K., Salomo, S., Kock, A. 2011. Top Management team diversity and strategic innovation orientation: The relationship and consequences for innovativeness and performance. J. Product Innov. Manag. 28(6), 819-832.

Zahra, S. A. 2003. International expansion of US manufacturing family Bus.es: The effect of ownership and involvement. J. Bus. Ventur. 18(4), 495-512.

Zhang, X., Ma, X., Wang, Y., Li, X., Huo, D. 2015. What drives the internationalization of Chinese SMEs? The joint effect of international entrepreneurship characteristics, network ties, and firm ownership. Int. Bus. Review 25(2), 522-534. 